\title{
Article
}

\section{Finger licking good? An observational study of hand hygiene practices of fast food restaurant employees and consumers}

\author{
Soon, Jan Mei \\ Available at http://clok.uclan.ac.uk/24708/ \\ Soon, Jan Mei ORCID: 0000-0003-0488-1434 (2019) Finger licking good? An \\ observational study of hand hygiene practices of fast food restaurant \\ employees and consumers. British Food Journal, 121 (3). pp. 697-710. ISSN \\ 0007-070X
}

It is advisable to refer to the publisher's version if you intend to cite from the work. http://dx.doi.org/10.1108/BFJ-07-2018-0420

For more information about UCLan's research in this area go to http://www.uclan.ac.uk/researchgroups/ and search for <name of research Group>.

For information about Research generally at UCLan please go to http://www.uclan.ac.uk/research/

All outputs in CLoK are protected by Intellectual Property Rights law, including Copyright law. Copyright, IPR and Moral Rights for the works on this site are retained by the individual authors and/or other copyright owners. Terms and conditions for use of this material are defined in the policies page.

\section{CLoK}

Central Lancashire online Knowledge www.clok.uclan.ac.uk

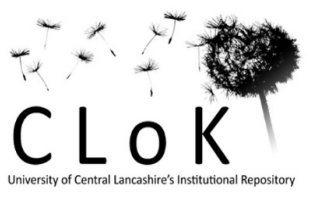




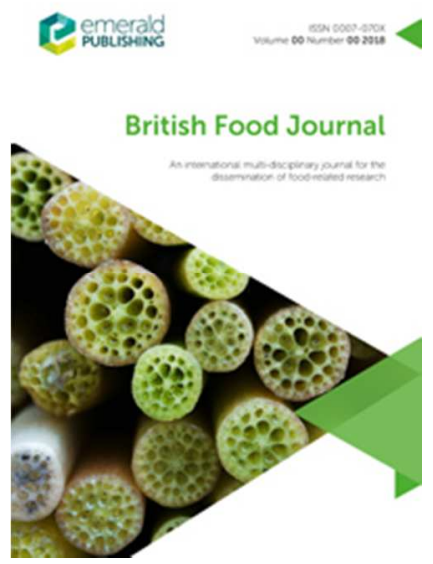

Finger licking good? An observational study of hand hygiene practices of fast food restaurant employees and consumers

\begin{tabular}{|r|l|}
\hline Journal: & British Food Journal \\
\hline Manuscript ID & BFJ-07-2018-0420.R1 \\
\hline Manuscript Type: & Research Paper \\
\hline Keywords: & Behaviour, food handlers, Food safety, handwashing, sanitation \\
\hline \multicolumn{2}{|l}{} \\
\hline
\end{tabular}

SCHOLARONE ${ }^{m}$

Manuscripts 


\title{
Finger licking good? An observational study of hand hygiene practices of fast food restaurant employees and consumers
}

\author{
Abstract \\ Purpose: Appropriate hand hygiene technique is a simple and effective method to reduce cross \\ contamination and transmission of foodborne pathogens. This study aims to investigate the frequency \\ of hand hygiene activities among food handlers and consumers in fast food restaurants. \\ Methodology: Twenty-five fast food restaurants and cafes were visited between May - August 2017 in
} North West England. A hand hygiene observational tool was adapted and modified from previous studies. The observational tool was designed to record 30 sequential hand activities of consumers and employees. Each transaction consisted of an observed action (e.g. touch with bare hands), object (e.g. exposed ready-to-eat foods) and observed hand hygiene practice (e.g. handwashing or cleaning with wipes or sanitisers). Adenosine triphosphate (ATP) swabs of hand-contact surfaces of restaurants' restrooms were carried out.

Findings: Findings revealed that both food handlers and consumers have low hand hygiene compliance rate in fast food restaurants. Consumers were more likely to clean their hands with napkins after handling exposed ready-to-eat (RTE) food. Food handlers were observed to change into new gloves without washing their hands before handling exposed RTE food. The mean results for all hand-contact surfaces in restrooms were higher than 30 Relative Light Units (RLUs) indicating unhygienic surfaces. Male restroom exit doors' adenosine triphosphate (ATP) levels were significantly higher than females.

Originality: This study revealed the lack of hand hygiene practices among food handlers and consumers at fast food restaurants and cafes. Restroom hand-contact surfaces revealed high ATP level indicating unhygienic surfaces. This can potentially re-contaminate washed hands upon touching unhygienic surface (e.g. exit door panel/handle) when leaving the restroom.

Keywords: behaviour; food handlers; food safety; handwashing; sanitation

\section{Introduction}

The World Health Organization (WHO) estimated that 31 foodborne hazards resulted in 600 million foodborne illnesses and more than 400,000 deaths in 2010 (WHO, 2015). In the UK, it is estimated that about a million people are affected by foodborne illnesses annually, leading to 20,000 hospitalisation and 500 deaths. It costs the UK about $£ 1.5$ billion and places a significant burden on the productivity and socio-economic development of the country (FSA, 2011). 
Eating out is becoming more prevalent as consumers spent more than $£ 1.47$ trillion worldwide while UK consumers spent a total of $£ 77$ billion eating out in restaurants and cafes in 2015 (Edwards, 2013; Statista, 2017). However, restaurants have been linked to foodborne illnesses such as the multistate outbreaks of Shiga toxin producing Escherichia coli 026 in Chipotle Mexican Grill (CDC, 2016), community outbreak of Salmonella enterica serotype Typhimurium in two local restaurants (Holman, et al., 2014) and norovirus outbreaks among diners at restaurants (Smith et al., 2012; Westrell et al., 2010).

Although no single food item or ingredient were-was implicated in the E. coli 026 outbreak, it is likely that a common meal item or ingredient served at the restaurants in different states were-was the likely source of outbreaks (CDC, 2016). Meanwhile the Salmonella outbreak was traced to an asymptomatic chef who worked at both restaurants (Holman et al., 2014). The norovirus outbreak were-was potentially caused by consumption of raw oysters, transmisstion from infected food handlers or due to the restaurant environment (Smith et al., 2012; Westrell et al., 2010). Food handlers represent the critical, final stage of food production, where meals are prepared and delivered. This group is also a reservoir of pathogens, and may not always be aware if they are transmitting pathogens (Todd et al., 2008). Food workers who do not adhere to safe and hygienic practices can potentially transmit pathogens to food and food contact surfaces. However, in addition to food workers, consumers may sometimes be the source of outbreaks (Todd et al., 2007). For example, in a restaurant setting where food from a common shared platter was eaten with fingers, it is likely that guests or staff introduced the norovirus into the shared dish causing three successive gastroenteritis outbreaks (Marshall et al., 2001).

Previous studies on food safety knowledge, attitude and practices among employees and consumers (Samapundo et al., 2016; Tomaszewska et al., 2018; Zanin et al., 2017) were based on self-reported practices. Zanin et al. (2017) identified 36 studies that addressed food safety knowledge, attitudes and practices of food handlers but most_still a lack of translation of knowledge/attitudes into practices. Studies on observation of food safety practices had been carried out using cameras (Evans and Redmond, 2018; Masson et al., 2017), direct observation (Her et al., 2017; Ovca et al., 2018) and discrete observation (Trafialek et al., 2017). Hand hygiene is an effective method to reduce cross contamination and transmission of foodborne pathogens (Ali et al., 2014). However, previous studies have shown that adherence to hand hygiene by food handlers is poor (Clark et al., 2018; do Prado et al., 2015; Robertson et al., 2013) whilst hand hygiene studies among consumers are still lacking. Similarly, a number of Adenosine Triphosphate (ATP) hygiene monitorings had been carried out in hospitals (Alfa et al., 2015; Amodio and Dino, 2014), kitchen (Aycicek et al., 2006) and food production facilities (Lau et al., 2016). But there is still a paucity of research on the hygienic status of hand-contact surfaces in restrooms. There was one_published study on ATP swabs of restroom sinks and stall doors conducted by Shaughnessy et al. (2013). Thus, it is the aim of this study to 
observe hand hygiene practices of both consumers and employees and to determine the ATP level of hand-touch surfaces of restroom facilities in fast food restaurants.

\section{Methodology}

\section{Hand hygiene observational tool}

The indications for hand hygiene were based on WHO (2009) and FSA (2013). The following criteria necessitates handwashing: when entering the food handling area (e.g. after a break or going to the toilet), before preparing food, after touching raw food, after handling food waste or bin, after cleaning, after blowing their nose, after touching phones, cash registers, door handles, light switches and surfaces that could come into contact with staff handling raw food. Hand hygiene technique includes handwashing with soap and water. The procedure takes between $40-60$ seconds. Hygienic hand rubs or gels should not be used in replacement for effective handwashing but could be used as an additional precaution. Similarly, food handlers must wash their hands thoroughly before putting on disposable gloves and after taking them off (FSA, n.d.).

Hand hygiene criteria for consumers include before handling and consuming exposed $\underline{\text { RReady-to-eat }}$ food, after handling food waste or touching the bin, after blowing their nose and touching electronic devices, cash and unhygienic surfaces. Objects such as mobile phones, tablets or other personal electronic devices (Lando et al., 2018; Walia et al., 2014), currencies (Alemu, 2014; Vriesekoop et al., 2010) had been found to harbour a range of pathogens and potential pathogens. A number of food contact surfaces such as cooking equipment, tray and utensils were contaminated with one or more food allergens (Ortiz et al., 2018). Personal items such as wallets, pens and purse were found positive for yeast and mould and Staphylococcus aureus (Donofrio et al., 2012). Handwashing, cleaning hands with wipes or sanitisers and handwashing and changing into new gloves were categorised as hand hygiene activities. An additional category of cleaning hands with napkins among consumers or cleaning hands with towels among food handlers were also recorded (but not categorised as hand hygiene activity). Observed behaviours that require hand hygiene activity were divided into foodrelated behaviour (i.e. before and after handling exposed food), after handling unsanitary objects, equipment and body parts. The observational tool used to monitor hand hygiene practices among consumers and employees was adapted from Behnke et al. (2012), Clayton and Griffith (2004) and Her et al. (2017). The observational tool was designed to record 30 sequential hand activities of consumers and employees. Her et al. (2017)'s tool was built using a mobile-friendly web-based survey platform to increase its ease of use, portability and reduces the Hawthorne effect of direct observation of consumers and staff. The author adopted a similar approach and developed the observational tool using Survey Monkey ${ }^{\circledR}$ survey platform with an android phone.

\section{Pilot testing and modification of observational tool}


114 The observational tool was pilot-tested in three fast food restaurants and one cafe at both peak (12 $2 \mathrm{pm})$ and non-peak hours $(3-5 \mathrm{pm})$ in Preston, UK. The 30 observations required a larger screen to determine the category of hand hygiene behaviour and actions. The scrolling and initiation of a new survey for new observation slowed the process down and the author adapted the instrument into an MS Excel sheet in a tablet. This allows a bigger screen to note down the actions, objects and hand hygiene practices that follow. The adaptation of the tool in MS Excel also excludes the need for Internet access and allows the usage of the tool in restaurants or cafes with limited wifi. There are two versions of the tool - one for the employee and one for consumers. After pilot testing the observational tool, observed actions such as 'finger licking', 'scratching' and use of unsanitary object such as 'cigarette' were added.

\section{Sampling of food service outlets}

Fast food outlets and cafes located in cities of North West England (Chester, Cumbria, Greater Manchester, Lancashire and Merseyside) were visited between May - August 2017. The author requested for-consent from the restaurant managers to carry out the study. The food handlers and consumers were not aware of the study to prevent the Hawthorne effect. The participants were only observed either during peak $(12-2 \mathrm{pm})$ and non-peak hours $(3-5 \mathrm{pm})$. Fast food operations were defined as outlets that offer standardised and simple menus within a controlled operating system (Jones et al., 2002). All fast food restaurants and cafes in this study consisted of facilities for customers to consume food on the premises. The fast food restaurants and cafes include those that sell burgers, pizza, sandwiches and finger food. Convenience sampling was used due to resource limitations and better access to fast food restaurants and cafes located in city centre or towns. A total of 25 restaurants were visited and 29 restrooms were swabbed.

\section{Hand hygiene observation}

During the start of each observation, the date, location and demographics such as gender, consumers' group size (e.g. 1, 2, 3 or more than 3) and employee working position (e.g. front service, cashier, food preparation/cooking) was recorded. Both consumers and employees were observed until 30 sequential behavioural transactions were recorded. Observation of consumers who left the restaurant or employees who left their workplace resulting in a lag in observation or less than 30 sequential transactions were discontinued. Each transaction consisted of an observed action (e.g. touch with bare hands), object (e.g. exposed ready-to-eat foods) and observed hand hygiene practice (e.g. handwashing). The type of objects are divided into food (e.g. exposed or wrapped foods), unsanitary object (e.g. electronic device), equipment (e.g. table) and human (e.g. body parts).

\section{Adenosine triphosphate hygiene monitoring of hand-contact surfaces in restaurants' restrooms} A $10 \times 10 \mathrm{~cm}^{2}$ area or contact area of various restroom spaces and touch surfaces were swabbed using Ultrasnap ATP and Hygiena Ensure Version 2 ATP hygiene monitoring system (Hygiena LLC, Ca, 
USA). Number of cubicles in each restroom (such as multi-use where there are 2 or more toilet cubicles) or single use (i.e. for male, female and disabled usage) were recorded. Between 5 - 7 surfaces were swabbed including toilet flush, cubicle lock and/or handle, sink faucet control, soap dispenser, hand drying controls and exit door in each restaurant's restroom. Swabbed samples were activated and recorded using the ATP luminometer. Results were expressed numerically as relative light units (RLUs). Score-A score of 10.00 RLUs or less is considered "satisfactory-/-pass"; scores from $11.00-30.00$ are considered "requires improvement-/-caution"; and a score of greater than 30.00 RLU-is considered_as a "fail" (Hygiena, 2018; Lau et al., 2016).

\section{Statistical analysis}

Descriptive statistics, chi-square test and univariate Analysis of Variance were carried out using IBM SPSS Statistics Version 24 and significance was set at $p<0.05$. Shapiro-Wilk test values of $>0.05$ were used to determine tests of normality whilst homogeneity of variance were checked using scatterplots.

\section{Results}

Demographics

Twenty-five fast food restaurants were visited. A total of 151 consumers and 47 employees were observed (Table 1). There were more females and Caucasians observed for both food handlers and consumers. More cashiers and servers were observed in the study as they represent the front service staff and their hand hygiene activities can be easily viewed and recorded. More than $80 \%$ of the observed consumers tend to dine in a party size of two or more people.

Insert Table 1 here

\section{Hand hygiene practices among consumers and employees}

A total of 4530 hand activities were observed among 151 consumers. Out of the 4,530 transactions, 33,010 required hand hygiene activity. However, consumers only practised hand hygiene activity (i.e. cleaning hands with wipes or sanitisers) in $0.33 \%$ of the transactions. The highest hand hygiene requirement was before handling exposed RTE (42.32\%) but consumers only cleaned their hands less than $1 \%$ of the time. The highest cleaning frequency was after handling exposed ready-to-eat food (RTE) (Table 2). There's a higher number of hand hygiene activity post-handling exposed RTE food There was no or very little hand hygiene activity after handling electronic devices, personal belongings or even after handling cigarettes. About $30 \%$ of the hand activities involved touching faces, hair, other body parts, finger licking and sneezing or coughing but only one consumer was observed to carry out hand sanitisation. There was a higher rate of cleaning hands with napkins (although this is not categorised as hand hygiene). Most consumers were observed to wipe their hands with napkins post-handling exposed RTE food (5.80\%) as most RTE food from fast food 
restaurants are in the form of finger foods such as burgers, fries, sandwiches, bakery products and

191

192

193

194

195

196

197

198

199

200

201

202

203

204

205

206

207

208

209

210

211

212

213

214

215

216

217

218

219

220

221

222

223

224

225

226

227 chicken pieces.

One thousand four hundred and 10 hand activities were observed among 47 food handlers of which 1157 required hand hygiene practices. The highest frequency of hand hygiene activity (21.28\%) were observed before handling exposed RTE food while no hand hygiene was carried out before putting on new gloves, after handling exposed RTE, unsanitary objects or body parts (Table 3). However, food handlers who changed into new gloves (21.28\%) did not wash their hands before putting them on. Out of the 274 equipment related behaviour requiring hand hygiene activity, only one staff was observed to clean her hands with napkins after handling the cooking equipment.

Insert Table 2 here

Insert Table 3 here

There was no significant association between food handlers and consumers' hand hygiene activity $X^{2}$ $=3.18(1), p>0.05$. There were no statistically significant associations between employees' working position or gender and hand hygiene activities. Among consumers, females (10.30\%) were more likely to clean their hands with wipes ef or sanitisers compared to males (0\%) $X^{2}=5.96(1), p<0.05$. Consumers with a party size of three or more people (13\%) were more likely to carry out hand hygiene activity $X^{2}=6.36(2), p<0.05$. Females were also observed to use their phones $(64.80 \%)$, touched their faces (67.14\%) and hair (82.56\%) more often compared to males- (Table 4 ).

Insert Table 4 here

\section{ATP swabs of restrooms}

A total of 16 female, 6 male and 7 unisex restrooms were swabbed. Fifteen were single-use type whilst the rest were categorised as multi-use (e.g. with 2 toilet cubicles or more). There was a wide variation in ATP results but the mean results for all surfaces were higher than 30 RLUs. This indicates that the surface areas were unhygienic and require re-cleaning (Hygiena, 2018). Fast Food Restaurant (FFR) 1 recorded the highest level of ATP across all surfaces (Figure 1). Out of the 29 restrooms, two facilities did not have soap and one hand dryer was not working. Among the facilities, there were 27 facilities with sensor-operated hand dryers, four sensor-operated faucets and two sensor-operated flush. Toilet flushes, sink faucets, soap dispensers and restroom exit doors were significantly higher in FFR1 compared to other FFRs (Table 5). Male restrooms recorded highest values across all surfaces except door locks. Male restroom exit doors' swabs were significantly higher than females $(p<0.05)$. 
Insert Figure 1 here

Insert Table 5 here

\section{Discussion}

The findings in this study revealed no signficant difference between food handlers and consumers in hand hygiene activities. Both groups have low hand hygiene compliance rate in fast food restaurants. Although food handlers involved in food preparation/cooking were more likely to clean their hands, this did not differ significantly from those who serves/work as cashiers. Fast food employees are expected to serve a large number of people with minimum waiting time. In order to be effective, fast food restaurants need to provide quality, consistent and timely meals and services. Jones et al. (2002) reported that fast food retailing in the UK aims to serve customers within three minutes of their entry into the restaurants. Fast food franchises rely on satisfied customers to continue their patronage at the premises (Gilbert et al., 2004; Namin, 2017). Based on the constant demand and time pressure, there is less opportunity for food handlers to carry out hand hygiene activities. This is in agreement with Thaivalappil et al., (2018) who found that handwashing was often not carried out during busy periods.

Lack of space and resources such as soap and poor accessibility to handwashing facilities also contribute to reduced adherence to food safety practices (Clayton et al., 2015). Strategic placement of hand hygiene foam dispensers were found to significantly increased the use of the dispenser (Thomas et al., 2009). Social norms too can influence food handlers' adherence to hand hygiene activities. Support and guidance from managers or supervisors and co-workers will create a positive food safety culture and better conformance to hand hygiene activity (Pragle et al., 2007). Perceptions of optimistic bias among food handlers where they perceived themselves as less likely than their peers to transmit foodborne diseases too can cause food handlers to overlook the food safety procedures. Optimistic bias among food handlers can lead to food safety breaches as an optimistic food handler may overlook hand hygiene practices and contaminate food products (da Cunha et al., 2014; Rossi et al., 2017). Timely and correct handwashing is important to prevent spread of pathogens. Handwashing is required before preparing food, after handling raw food, when entering the food preparation area, after going to the toilet or break, after touching bins and items such as door handles, light switches, cash registers, after blowing their nose or changing a dressing. Employees should be reminded that disposable gloves are not to be used as an alternative hand hygiene activity (FSA, 2013).

Consumers were more likely to clean their hands with napkins. Although the customers in this study were observed for an average of 8 minutes per 30 sequential transactions, Paddock et al. (2017) revealed that customers spend an average of 1 hour or less in the restaurant. This provides 
customers with time to carry out hand hygiene activity. A high number of transactions also involved customers touching their mobile phones and skin (especially facial area) and this could have triggered customers to wipe their hands before using their phones or touching their faces. Consumers who tend to lick their fingers did not clean their hands after licking. In fact, "'finger-lickin' good" is a famous catchphrase of a well-known fast food brand and signifies that customers will not be able to resist polishing the food off their fingers (Visser, 2017). However, finger licking is not an acceptable dining etiquette in some culture (Visser, 2017) nor an appropriate food safety practice especially when preparing food (Eves et al., 2006). Finger licking behaviour were also observed in popular television cooking shows where 47 finger licking behaviour were observed in the shows (Irlbeck et al., 2009).

Females were observed to clean their hands more frequently. Females also tend to touch their phones, face and hair more often compared to males. Her et al. (2017) observed similar behaviour among females in their study. Females were more likely to experience social physique anxiety (Kowalski et al., 2006) and tend to address the anxiety via appearance management and repetitive body checking behaviour (Haase et al., 2007; Reilly and Rudd, 2009; White and Warren, 2014). In this study, there was also one observation of a consumer who picked a dead fly from the table but did not clean her hands prior to eating. Flies may transmit pathogens to food or hands. Previous studies reported that houseflies can transmit Escherichia coli (Lindeberg et al., 2018; Talley et al., 2009) and Salmonella enterica (Pace et al., 2017) to food. A party size of three and above encourages hand hygiene activities and this could be due to subjective norm effects where individuals are influenced or pressured to comply with expectations from other individuals (Ajzen, 1985).

RLU scores greater than 30.00 indicated a fail, demonstrating that the surface areas highlighted as human touch points should be re-cleaned. The ATP on the surfaces may have derived from food residues, dead microorganisms or hand ATP (Worsfold and Griffith, 2001). Additionally, aerosol contamination of surfaces generated from the action of flushing can contribute to the high surface ATP reading. Barker and Jones (2005) simulated the effects of flushing a toilet and recorded the spread of aerosol contamination of surfaces. They found bacterial contamination of between $20-50$ CFU per plate on the toilet seat, shelf, cistern and front of toilet within 30 minutes of flushing. The surface ATP in FF1 increased progressively from toilet stall doors to soap dispensers although the ATP reading declined $23 \%$ on the restroom exit door. The high number of surface ATP in this study is a cause for concern as the effectiveness of handwashing practices may diminish post-handwashing when touching the sink faucet and restroom door handle / panel to exit. Posting reminders or reinforcement such as effective handwashing steps, posters or consequences (e.g. fines, health violations) can influence food safety practices (Thaivalappil et al. 2018). Clark et al. (2018) developed the handwashing intervention ladder and suggested a number of methods to address the lack of hand hygiene compliance. This can potentially be applied in fast food restaurant settings to encourage food handlers and customers to wash their hands effectively. 


\section{Limitations}

306

Due to resource limitations, the researcher could only visit a small number of fast food restaurants and cafés and the outlets were only visited once. The outlets were also limited to those located in city or town centres. The current study was only conducted in North West England and the findings should not be generalised to other locations. It is recommended that future studies should include information on how frequently the restrooms were cleaned. ATP swabs could be conducted to determine the level of hygiene before and after cleaning and during peak and non-peak use.

\section{Conclusion}

The findings from this study revealed poor hand hygiene activities among food handlers and consumers at fast food restaurants. Food handlers were observed to change into new gloves before handling exposed RTE but did not clean their hands after handling food, unsanitary objects or touching their face or other body parts. Only female consumers were observed to clean their hands with wipes or sanitisers. Consumers were observed to clean their hands with napkins more often after handling exposed RTE compared to other surfaces. This study also revealed that the hand-contact surfaces in restrooms are unhygienic and can potentially re-contaminate washed hands upon touching unhygienic surfaces such as the exit door panel or handle. Reinforcement such as posters or reminders of risk of transmission of foodborne pathogens can help to increase hand hygiene compliance. Effective handwashing and hand hygiene activities are the best methods to prevent transmission of foodborne disease.

\section{References}

Ajzen, I. (1985). From intentions to actions: A Theory of Planned Behaviour. In, J. Kuhl and J. Beckmann (eds.). Action Control: From Cognition to Behaviour. Springer Berlin Heidelberg, pp. 11-39.

Alemu, A. (2014), "Microbial contamination of currency notes and coins in circulation: A potential public health hazard", Biomedicine and Biotechnology, Vol. 2 No. 3, pp. 46-53.

\section{Alfa, M. J., Olson, N. and Murray, B.-L. (2015), "Adenosine triphosphate (ATP)-based cleaning} monitoring in health care: how rapidly does environmental ATP deteriorate?" Journal of Hospital Infection, Vol. 90 No. 1, pp. 59-65. 358. 
341

342

343

344

345

346

347

348

349

350

351

352

353

354

355

356

357

358

359

360

361

362

363

364

365

366

367

368

369

370

371

372

373

374

375

376

Amodio, E. and Dino, C. (2014), "Use of ATP bioluminescence for assessing the cleanliness of hospital surfaces: A review of the published literature (1990-2012)", Journal of Infection and Public Health, Vol. 7 No. 2, pp. 92-98.

Aycicek, H., Oguz, U. and Karci, K. (2006), "Comparison of results of ATP bioluminescence and traditional hygiene swabbing methods for the determination of surface cleanliness at a hospital kitchen", International Journal of Hygiene and Environmental Health, Vol. 209 No. 2, pp. 203-206.

Barker, J. and Jones, M. V. (2005), "The potential spread of infection caused by aerosol contamination of surfaces after flushing a domestic toilet", Journal of Applied Microbiology, Vol. 99 No. 2, pp. 339-347.

Behnke, C., Seo, S. and Miller, K. (2012), "Assessing food safety practices in farmers' markets", Food Protection Trends, Vol. 32 No. 5, pp. 232-239.

CDC (2016), "Multistate outbreaks of Shiga toxin-producing Escherichia coli $\mathrm{O} 26$ infections linked to Chipotle Mexican Grill restaurants (Final update)", Center for Disease Control and Prevention.

Available at: https://www.cdc.gov/ecoli/2015/026-11-15/index.html [Accessed 16 Feb 2018].

Clark, J., Crandall, P. G. and O'Bryan, C. (2018), "Climbing the intervention ladder to handwashing compliance: A review and directions for future research", Food Control, Vol. 84, pp. 544-551.

Clayton, D. A. and Griffith, C. J. (2004), "Observation of food safety practices in catering using notational analysis", British Food Journal, Vol. 106 No. 3, pp. 211-227.

Clayton, M. L., Smith, K. C., Neff, R. A., Pollack, K. M. and Ensminger, M. (2015), "Listening to food workers: Factors that impact proper health and hygiene practice in food service", International Journal of Occupational and Environmental Health, Vol. 21 No. 4, pp. 314-327.

da Cunha, D. T., Stedefeldt, E. and de Rosso, V. V. (2014), "He is worse than I am: The positive outlook of food handlers about foodborne disease", Food Quality and Preference, Vol. 35, pp. 95-97.

Donofrio, R. S., Bechanko, R., Hitt, N., O' Malley, K., Charnauski, T., Bestervelt, L. L., Saha, R. and Saha, N. (2012), "Are we aware of microbial hotspots in our household?" Journal of Environmental Health, Vol. 75 No. 2, pp. 12-19. 
377 do Prado, D. B., Bettoni, A. P., Correa, V. A., de Abreu Filho, B. A., Garcia, L. B., Tognim, M. C. B. and 378 Cardoso, C. L. (2015), "Practice of hand hygiene in a university dining facility", Food Control, Vol. 57, 379 pp. $35-40$.

Edwards, J. S. A. (2013), "The foodservice industry: Eating out is more than just a meal", Food Quality and Preference, Vol. 27 No. 2, pp. 223-229.

Evans, E. W. and Redmond, E. C. (2018), "Behavioral observation and microbiological analysis of older adult consumer's cross contamination practices in a model domestic kitchen", Journal of Food Protection, Vol. 81 No. 4, pp. 569-581.

Eves, A., Bielby, G., Eqan, B., Lumbers, M., Raats, M. and Adams, M. (2006), "Food hyqiene knowledge and self-reported behaviours of UK school children", British Food Journal, Vol. 108 No. 9, pp. 706-720.

Ferguson, C. J. (2009), "An effect size primer: A guide for clinicians and researchers", Professional Psychology: Research and Practice, Vol. 40 No. 5, pp. 532-538.

FSA (n.d.), "Safe method: Handwashing. Effective handwashing is essential to help prevent bacteria spreading to food", Available at:

https://www.food.gov.uk/sites/default/files/multimedia/pdfs/publication/handwashing-sfbb-0513.pdf [Accessed 26 April 2018]

FSA (2011), "Foodborne disease strategy 2010-2015", Food Standards Agency. Available at: https://www.food.gov.uk/sites/default/files/multimedia/pdfs/fds2015.pdf [Accessed 17 February 2018].

FSA (2013), "Food hygiene: A guide for businesses", Food Standards Agency. Available at: https://www.food.gov.uk/sites/default/files/multimedia/pdfs/publication/hygieneguidebooklet.pdf [Accessed 29 May 2018]

Gilbert, G. R., Veloutsou. C., Goode, M. M. H. and Moutinho, L. (2004), "Measuring customer satisfaction in the fast food industry: a cross-national approach", Journal of Services Marketing, Vol. 18 No. 5, pp. 371-383.

Haase, A. M., Mountford, V. and Waller, G. (2007), "Understanding the link between body checking cognitions and behaviors: The role of social physique anxiety", International Journal of Eating Disorders, Vol. 40 No. 3, pp. 241-246. 
Her, E., Seo, S., Choi, J., Pool, V. and Ilic, S. (2017), "Observed food safety behaviors among

417 consumers and employees in university food courts", British Food Journal, Vol. 119 No. 7, pp.16191632.

419

Holman, E. J., Allen, K. S., Holguin, J. R., Torno, M., and Lachica, M. (2014), "A community outbreak of Salmonella enterica serotype Typhimurium associated with an asymptomatic food handler in two local restaurants", Journal of Environmental Health, Vol. 77 No. 2, pp. 18-20.

423

Hygiena (2018), "EnSure", Available at: https://www.hygiena.com/other-products/ensure-other.html

426

427

428

429

Jones, P., Shears, P., Hillier, D. and Clarke-Hill, C. (2002), "Customer perceptions of services brands:

431 a study of the three major fast food retailers in the UK", Management Research News, Vol. 25 No.

432 6/7, pp. 41-49.

433

Kowalski, K. C., Mack, D. E., Crocker, P. R. E., Niefer, C. B. and Fleming, T.-F. (2006), "Coping with

435 social physique anxiety in adolescence", Journal of Adolescent Health, Vol. 39 No. 2, pp. 275. e9 275.e16.

437

Lando, A. M., Bazaco, M. C. and Chen, Y. (2018), "Consumers' use of personal devices in the kitchen", Journal of Food Protection, Vol. 81 No. 3, pp. 437-443.

Lau, A. N., Jamaludin, M. H., and Soon, J. M. (2016), "Quality assurance and halal control points for the food industry", Nutrition and Food Science, Vol. 46 No. 4, pp. 557-570.

443

Lindeberg, Y. L., Egedal, K., Hossain, Z. Z., Phelps, M., Tulsiani, S., Farhana, I., Begum, A. and Jensen, P. K. M. (2018), "Can Escherichia colifly? The role of flies as transmitters of E. coli to food in an urban slum in Bangladesh", Tropical Medicine and International Health, Vol. 23 No. 1, pp. 2-9.

Marshall, J. A., Yuen, L. K. W., Catton, M. G., Gunesekere, I. C., Wright, P. J., Bettelheim, K. A., Griffith, J. M., Lightfoot, D., Hogg, G. G. , Gregory, J., Wilby, R. and Gaston, J. (2001), "Multiple outbreaks of Norwalk-like virus gastro-enteritis associated with a Mediterranean-style restaurant", 
Masson, M., Delarue, J. and Blumenthal, D. (2017), "An observational study of refrigerator food storage by consumers in controlled conditions", Food Quality and Preference, Vol. 56 (Part B), pp. 294-300.

Namin, A. (2017), "Revisiting customers' perception of service quality in fast food restaurants", Journal of Retailing and Consumer Services, Vol. 34, pp. 70-81.

Ortiz, J. C., Galan-Malo, P., Garcia-Galvez, M., Mateos, A., Ortiz-Ramos, M., Razquin, P. and Mata, L. (2018), "Survey on the occurrence of allergens on food-contact surfaces from school canteen kitchens", Food Control, Vol. 84, pp. 449-454.

Ovca, A., Jevsnik, M., and Raspor, P. (2018), "Food safety practices of future food handlers and their teachers observed during practical lessons", British Food Journal, Vol. 120 No. 3, pp. 531-548.

Pace, R. C., Talley, J. L., Crippen, T. L. and Wayadande, A. C. (2017), "Filth fly transmission of Escherichia coli 0157:H7 and Salmonella enterica to lettuce, Lactuca sativa", Annals of the Entomological Society of America, Vol. 110 No. 1, pp. 83-89.

Paddock, J., Warde, A. and Whillans, J. (2017), "The changing meaning of eating out in three English cities 1995-2015", Appetite, Vol. 119, pp. 5-13.

Pragle, A. S., Harding, A. K. and Mack, J. C. (2007), "Food workers' perspectives on handwashing behaviors and barriers in the restaurant environment", Journal of Environmental Health, Vol. 69 No. 10 , pp. 27-32.

Reilly, A. and Rudd, N. A. (2009), "Social anxiety as predictor of personal aesthetic among women", Clothing and Textiles Research Journal, Vol. 27 No. 3, pp. 227-239.

Robertson, L. A., Boyer, R. B., Chapman, B. J., Eifert, J. D. and Franz, N. K. (2013), "Educational needs assessment and practices of grocery store food handlers through survey and observational data collection", Food Control, 34(2), 707-713.

Rossi, M. d. S. C., Stedefeldt, E., de Cunha, D. T. and de Rosso, V. V. (2017), "Food safety knowledge, optimistic bias and risk perception among food handlers in institutional food services", Food Control, Vol. 73 No. Part B, pp. 681-688. 
489 Samapundo, S., Cam Thanh, T. N., Xhaferi, R. and Devlieghere, F. (2016), "Food safety knowledge, 490 attitudes and practices of street food vendors and consumers in Ho Chi Minh city, Vietnam", Food 491 Control, Vol. 70, pp. 79-89.

492

493 Shaughnessy, R. J., Cole, E. C., Moschandreas, D. and Haverinen-Shaughnessy, U. (2013), "ATP as a 494 marker for surface contamination of biological origin in schools and as a potential approach to the 495 measurement of cleaning effectiveness", Journal of Occupational and Environmental Hygiene, Vol. 10

497

Smith, A. J., McCarthy, N., Saldana, L. and Ihekweazu, C. (2012), "A large outbreak of norovirus in 499 diners at a restaurant in England between January and February 2009", Epidemiology and Infection, Vol. 140 No. 9, pp. 1695-1701.

501

Statista (2017), "Restaurant industry in the United Kingdom (UK) - Statistics and facts", Available at: https://www.statista.com/topics/3131/restaurant-industry-in-the-united-kingdom-uk/ [Accessed 18 April 2018]

505

Talley, J. L., Wayadande, A. C., Wasala, L. P., Gerry, A. C., Fletcher, J., DeSilva, U. and Gilliland, S. E. 507 (2009), "Association of Escherichia coli O157:H7 with filth flies (Muscidae and Calliphoridae) captured in leafy green fields and experimental transmission of E. coli O157:H7 to spinach leaves by houseflies (Diptera: Muscidae)", Journal of Food Protection, Vol. 72 No. 7, pp. 1547-1552. thematic synthesis of qualitative research studies on factors affecting safe food handling at retail and food service", Food Control, Vol. 89, pp. 97-107. product usage in an intensive care unit", Journal of the American Osteopathic Association, Vol. 109 No. 5, pp. 263-267.

Todd, E. C., Greig, J. D., Bartleson, C. A., and Michaels, B. S. (2007), "Outbreaks where food workers have been implicated in the spread of foodborne disease. Part 3. Factors contributing to outbreaks and description of outbreak categories", Journal of Food Protection, Vol. 70 No. 9, pp. 2199-2217.

524 Todd, E. C., Greig, J. D., Bartleson, C. A. and Michaels, B. S. (2008), "Outbreaks where food workers 525 have been implicated in the spread of foodborne disease. Part 4. Infective doses and pathogen 526 carriage2, Journal of Food Protection, Vol. 71 No. 11, pp. 2339-2373. 
528 Tomaszewska, M., Trafialek, J., Suebpongsang, P. and Kolanowski, W. (2018), "Food hygiene

529 knowledge and practice of consumers in Poland and in Thailand - A survey", Food Control, Vol. 85, $53076-84$.

531

532 Trafialek, J., Drosinos, E. H. and Kolanowski, W. (2017), "Evaluation of street food vendors' hygienic practices using fast observation questionnaire", Food Control, Vol. 80, pp. 350-359.

534

535

536

537

538

539

540

541

542

543

544

545

546

547

548

549

550

551

552

553

554

555

556

557

558

559

560

561

562

563

564
Visser, M. (2017), "The rituals of dinner: The origins, evolution, exxentricities and meaning of table manners", Penguin UK, pp. 1-448.

Vriesekoop, F., Russell, C., Alvarez-Mayorga, B., Aidoo, K., Yuan, Q., Scannell, A. et al. (2010), "Dirty money: An investigation into the hygiene status of some of the world's currencies as obtained from food outlets", Foodborne Pathogens and Disease, Vol. 7 No. 12, pp. 1497-1502.

Walia, S. S., Manchanda, A., Narang, R. S., Anup, N., Singh, B. and Kahlon, S. S. (2014), "Cellular telephone as reservoir of bacterial contamination: Myth or fact", Journal of Clinical and Diagnostic Research, Vol. 8 No. 1, pp. 50-53.

Westrell, T., Dusch, V., Ethelberg, S., Harris, J., Hjertqvist, M., Jourdan-da Silva, N., Koller, A., Lenglet, A., Lisby, M. and Vold, L. (2010), "Norovirus outbreaks linked to oyster consumption in the United Kingdom, Norway, France, Sweden and Denmark, 2010", Eurosurveillance, Vol. 15 No. 12, pp. pii $=19524$.

White, E. K. and Warren, C. S. (2014), "The influence of social anxiety on the body checking behaviors of female college students", Body Image, Vol. 11 No. 4, pp. 458-463.

WHO (2009), "WHO guidelines on hand hygiene in health care: a summary", Available at: http://www.who.int/gpsc/5may/tools/who guidelines-handhygiene summary.pdf [Accessed 26 June 2018]

WHO (2015), "WHO estimates of the global burden of foodborne diseases", Available at: http://apps.who.int/iris/bitstream/10665/200046/1/WHO FOS 15.02 eng.pdf?ua=1 [Accessed 17 February 2018]

Worsfold, D. and Griffith, C. J. (2001), "An assessment of cleaning regimes and standards in butchers' shops", International Journal of Environmental Health Research, Vol. 11 No. 3, pp. 245-256. 
565 Zanin, L. M., de Cunham, D. T., de Rosso, V. V., Capriles, V. D. and Stedefeldt, E. (2017), 566 "Knowledge, attitudes and practices of food handlers in food safety: An integrative review," Food 567 Research International, Vol. 100 No. 1, pp. 53-62. 


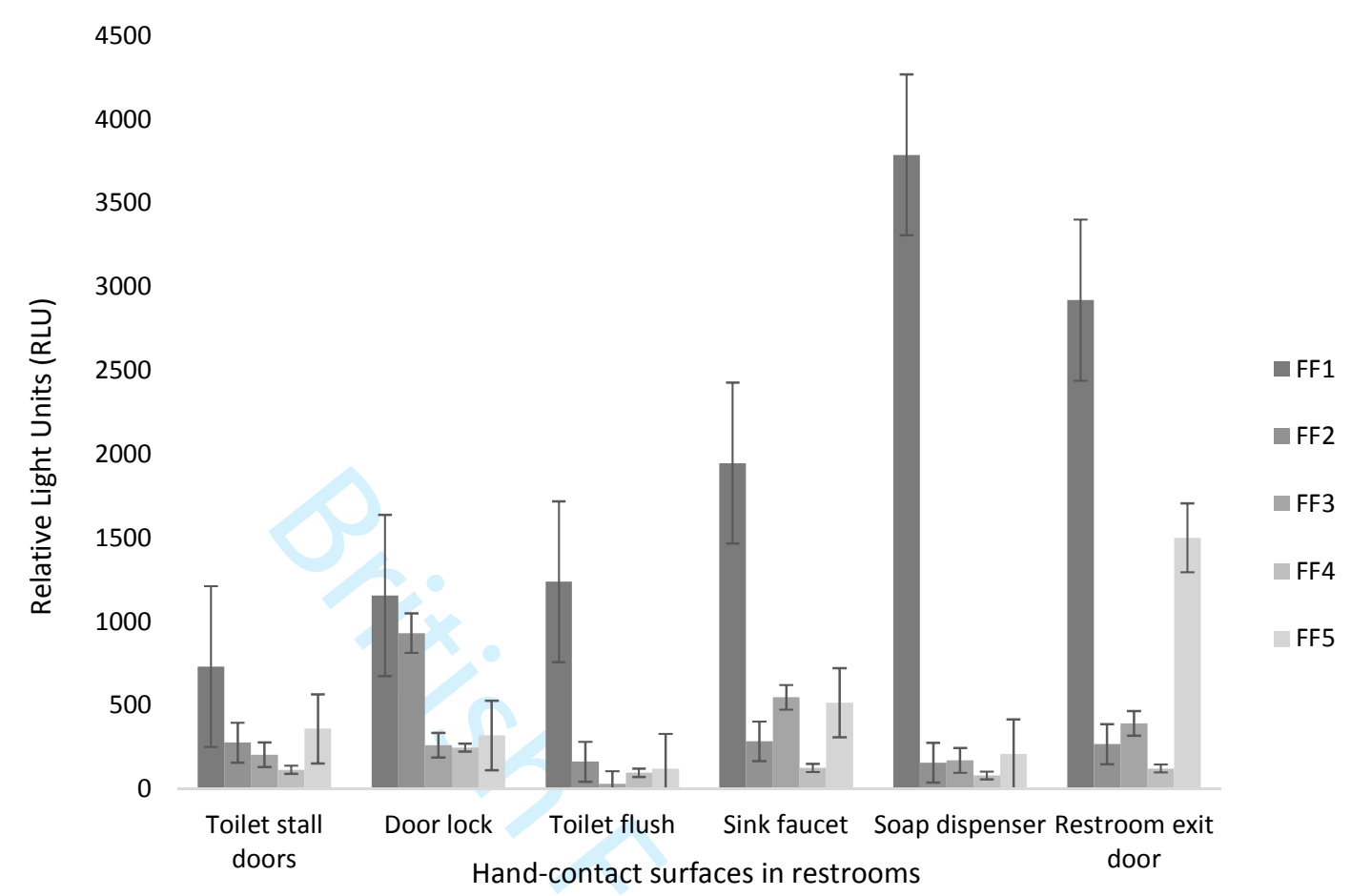

Figure 1. ATP levels (RLUs) of hand-contact surfaces in fast food restaurants' restrooms Notes: FFR1 - FFR4 represent individual leading fast food brands i.e. FFR1: Fast food restaurant that predominantly sells burgers and finger food; FF2 and FF3: burgers and fries; FF4: sandwiches and salad; FFR5 = others [made up of five fast food brands that sell pizza, burgers and sandwiches]; vertical bars = standard error; $n=29$ 
Table 1. Demographic characteristics of observed participants

\begin{tabular}{llll}
\hline \multicolumn{1}{c}{ Food handlers $(\mathbf{n = 4 7 )}$} & Number (\%) & Consumers (n=151) & Number (\%) \\
\hline Gender & $16(34.04)$ & Gender \\
Male & $31(65.96)$ & Male & $54(35.76)$ \\
Female & & Pemale & $97(64.24)$ \\
Employee working position & $17(36.17)$ & One & \\
Food preparation or cooking & $30(63.83)$ & Two & $30(19.87)$ \\
Cashier or serving & & Three and above & $67(44.37)$ \\
& & & $54(35.77)$
\end{tabular}


Table 2. Number of observed hand hygiene activity among consumers $(n=151)$

\begin{tabular}{|c|c|c|c|c|c|c|}
\hline \multirow[t]{2}{*}{$\begin{array}{l}\text { Behaviours requiring hand } \\
\text { hygiene practice }\end{array}$} & \multicolumn{2}{|c|}{$\begin{array}{c}\text { Number of } \\
\text { observations } \\
\text { requiring hand } \\
\text { hygiene }\end{array}$} & \multicolumn{2}{|c|}{$\begin{array}{l}\text { Observed hand } \\
\text { hygiene } \\
\text { practice }\end{array}$} & \multicolumn{2}{|c|}{$\begin{array}{l}\text { Observed other } \\
\text { forms of hand } \\
\text { cleaning activity }\end{array}$} \\
\hline & Number & $\%$ & Number & $\%$ & Number & $\%$ \\
\hline Food & & & & & & \\
\hline $\begin{array}{l}\text { Before handling exposed ready- } \\
\text { to-eat (RTE) food }\end{array}$ & 1274 & 42.32 & 3 & 0.23 & 30 & 2.35 \\
\hline Exposed RTE food & & & 4 & 0.31 & 74 & 5.80 \\
\hline Total & 1274 & 42.32 & 7 & 0.55 & 104 & 8.16 \\
\hline \multicolumn{7}{|l|}{ Unsanitary object } \\
\hline $\begin{array}{l}\text { Electronic device (mobile } \\
\text { phone, laptop, tablet) }\end{array}$ & 267 & 8.87 & 0 & 0 & 1 & 0.37 \\
\hline Paper (receipt, order receipt) & 43 & 1.43 & 0 & 0 & 0 & 0 \\
\hline Cash, credit card & 7 & 0.23 & 0 & 0 & 0 & 0 \\
\hline Condiments & 154 & 5.12 & & & 2 & 1.30 \\
\hline $\begin{array}{l}\text { Personal belongings (wallet, } \\
\text { purse, glasses, cap) }\end{array}$ & 159 & 5.28 & 2 & 1.26 & 0 & 0 \\
\hline Pencil / pen & 4 & 0.13 & 0 & 0 & 0 & 0 \\
\hline Cigarette & 6 & 0.20 & 0 & 0 & 0 & 0 \\
\hline $\begin{array}{l}\text { Others (e.g. tray, menu, bin } \\
\text { door, newspaper, walking aid) }\end{array}$ & 90 & 2.99 & 0 & 0 & 0 & 0 \\
\hline Total & 730 & 24.25 & 2 & 0.27 & 3 & 0.41 \\
\hline \multicolumn{7}{|l|}{ Equipment } \\
\hline Surface / table & 111 & 3.69 & 0 & 0 & 1 & 0.90 \\
\hline Door & 5 & 0.17 & 0 & 0 & 0 & 0 \\
\hline Other (e.g. vending machine) & 1 & 0.03 & 0 & 0 & 0 & 0 \\
\hline Total & 117 & 3.89 & 0 & 0 & 1 & 0.85 \\
\hline \multicolumn{7}{|l|}{ Human } \\
\hline $\begin{array}{l}\text { Body parts (e.g. face, nose, } \\
\text { ears) }\end{array}$ & 421 & 13.99 & 0 & 0 & 3 & 0.71 \\
\hline Other body parts & 69 & 2.29 & 0 & 0 & 2 & 2.90 \\
\hline Hair & 86 & 2.86 & 0 & 0 & 0 & 0 \\
\hline Cough, sneeze, spit & 11 & 0.37 & 0 & 0 & 0 & 0 \\
\hline Finger licking & 160 & 5.32 & 0 & 0 & 1 & 0.63 \\
\hline $\begin{array}{l}\text { Other (e.g. skin contact other } \\
\text { family members or friends) }\end{array}$ & 142 & 4.72 & 1 & 0.70 & 0 & 0 \\
\hline Total & 889 & 29.53 & 1 & 0.11 & 6 & 0.67 \\
\hline $\begin{array}{l}\text { Total number of } \\
\text { requirements and hand } \\
\text { hygiene activities }\end{array}$ & 3010 & & 10 & 0.33 & 114 & 3.79 \\
\hline
\end{tabular}

Total number of transactions - 4530; Hand hygiene activities among consumers include cleaning hands with wipes / sanitiser. Other observed form of hand cleaning activity was wiping with napkins (this is not categorised as hand hygiene) 
Table 3. Number of observed hand hygiene activity among employees $(n=47)$

\begin{tabular}{|c|c|c|c|c|}
\hline \multirow[t]{2}{*}{ Behaviours requiring hand hygiene practice } & \multicolumn{2}{|c|}{$\begin{array}{c}\text { Number of } \\
\text { observations } \\
\text { requiring hand } \\
\text { hygiene }\end{array}$} & \multicolumn{2}{|c|}{$\begin{array}{l}\text { Observed hand } \\
\text { hygiene practice } \\
\text { and other* } \\
\text { forms of hand } \\
\text { cleaning activity }\end{array}$} \\
\hline & Number & $\%$ & Number & $\%$ \\
\hline Food & & & & \\
\hline Before handling exposed food & 47 & 4.06 & 10 & 21.28 \\
\hline After handling exposed food & & & 0 & 0 \\
\hline Before putting on new gloves & 11 & 0.95 & 0 & 0 \\
\hline Other & 7 & 0.61 & 0 & 0 \\
\hline Total & 65 & 5.62 & 10 & 15.38 \\
\hline \multicolumn{5}{|l|}{ Unsanitary object } \\
\hline $\begin{array}{l}\text { Electronic device (mobile phone, laptop, tablet, } \\
\text { ordering machine, cash machine) }\end{array}$ & 185 & 15.99 & 0 & 0 \\
\hline Paper (receipt, order receipt) & 53 & 4.58 & 0 & 0 \\
\hline Cash, credit card & 93 & 8.03 & 0 & 0 \\
\hline Clothes, aprons, cap & 83 & 7.17 & 0 & 0 \\
\hline Condiments & 6 & 0.52 & 0 & 0 \\
\hline Bottled/cup beverage & 94 & 8.12 & 0 & 0 \\
\hline Pencil / pen & 5 & 0.43 & 0 & 0 \\
\hline Cleaning items (broom/dishcloth) & 61 & 5.27 & 0 & 0 \\
\hline $\begin{array}{l}\text { Other (e.g. tray, menu, dirty utensils, food } \\
\text { wastes, bin door) }\end{array}$ & 148 & 12.79 & 0 & 0 \\
\hline Total & 728 & 62.92 & 0 & 0 \\
\hline \multicolumn{5}{|l|}{ Equipment } \\
\hline Cooking equipment (grilling, deep fryer, pots) & 149 & 12.88 & $1^{*}$ & 0.67 \\
\hline Fridge / storage handle & 16 & 1.38 & 0 & 0 \\
\hline Surface / table & 96 & 8.30 & 0 & 0 \\
\hline $\begin{array}{l}\text { Other (e.g. drawer, dishwasher, ordering } \\
\text { machine) }\end{array}$ & 13 & 1.12 & 0 & 0 \\
\hline Total & 274 & 23.68 & $1^{*}$ & 0.36 \\
\hline \multicolumn{5}{|l|}{ Human } \\
\hline Body parts (face, nose) & 47 & 4.06 & 0 & 0 \\
\hline Hair & 10 & 0.86 & 0 & 0 \\
\hline Other body parts & 32 & 2.77 & 0 & 0 \\
\hline Other (e.g. scratching) & 1 & 0.09 & 0 & 0 \\
\hline Total & 90 & 7.78 & 0 & 0 \\
\hline $\begin{array}{l}\text { Total number of requirements and hand } \\
\text { hygiene activities }\end{array}$ & 1157 & 100 & 11 & 0.95 \\
\hline
\end{tabular}


Table 4. Cross-tabulations of hand hygiene practices

\begin{tabular}{|c|c|c|c|c|}
\hline Observed participants & $\begin{array}{l}\text { Har } \\
\text { obse }\end{array}$ & $\begin{array}{l}\text { ene } \\
(\%)\end{array}$ & $x^{2}$ & $p$ \\
\hline $\begin{array}{l}\text { Food handlers }(n=47) \\
\text { Consumers }(n=151)\end{array}$ & $\begin{array}{c}\text { Yes } \\
21.30 \\
10.30\end{array}$ & $\begin{array}{c}\text { No } \\
78.80 \\
89.70\end{array}$ & 3.18 & 0.12 \\
\hline $\begin{array}{l}\text { Food handlers } \\
\text { Male } \\
\text { Female }\end{array}$ & $\begin{array}{l}31.30 \\
16.10\end{array}$ & $\begin{array}{l}68.80 \\
83.90\end{array}$ & 1.44 & 0.20 \\
\hline $\begin{array}{l}\text { Food preparation / cooking } \\
\text { Cashier / serving }\end{array}$ & $\begin{array}{l}35.30 \\
13.30\end{array}$ & $\begin{array}{l}64.70 \\
86.70\end{array}$ & 3.12 & 0.14 \\
\hline $\begin{array}{l}\text { Consumers } \\
\text { Male } \\
\text { Female }\end{array}$ & $\begin{array}{c}0 \\
10.30\end{array}$ & $\begin{array}{c}100 \\
89.70\end{array}$ & 5.96 & 0.014 \\
\hline $\begin{array}{l}\text { Party size } \\
\text { One } \\
\text { Two } \\
\text { Three and above }\end{array}$ & $\begin{array}{c}6.70 \\
1.50 \\
13.00\end{array}$ & $\begin{array}{l}93.30 \\
98.50 \\
87.00\end{array}$ & 6.36 & 0.036 \\
\hline
\end{tabular}


Table 5. Univariate analysis of variance on the effect of fast food restaurants and type of restrooms on ATP level

\begin{tabular}{|c|c|c|c|c|c|c|}
\hline \multirow{2}{*}{$\begin{array}{c}\text { Dependent } \\
\text { variable }\end{array}$} & \multicolumn{3}{|c|}{ Fast Food Restaurants (*FFRs $1-5$ ) } & \multicolumn{3}{|c|}{ Restrooms (gender) } \\
\hline & $\mathrm{F}$ & $p$ value & $\eta^{2}$ & $\mathrm{~F}$ & $p$ value & $\eta^{2}$ \\
\hline $\begin{array}{l}\text { Toilet stall } \\
\text { doors }\end{array}$ & 1.315 & 0.329 & 0.345 & 0.086 & 0.918 & 0.014 \\
\hline Door lock & 1.363 & 0.276 & 0.185 & 0.374 & 0.692 & 0.028 \\
\hline Toilet flush & 31.358 & $<0.0001$ & 0.845 & 1.254 & 0.303 & 0.091 \\
\hline Sink faucet & 6.698 & 0.001 & 0.538 & 0.435 & 0.652 & 0.034 \\
\hline $\begin{array}{c}\text { Soap } \\
\text { dispenser }\end{array}$ & 195.292 & $<0.0001$ & 0.970 & 0.478 & 0.625 & 0.035 \\
\hline $\begin{array}{l}\text { Restroom } \\
\text { exit door }\end{array}$ & 17.838 & $<0.0001$ & 0.836 & 2.703 & 0.097 & 0.253 \\
\hline
\end{tabular}

